\title{
NEW URBAN ECONOMIC AGENTS: A COMPARATIVE ANALYSIS OF HIGH-PERFORMANCE NEW ENTREPRENEURS
}

\author{
Karima Kourtit ${ }^{1,2}$, Peter NijKamp ${ }^{2,3}$, Soushi Suzuki ${ }^{4}$ \\ ${ }^{1}$ KTH Royal Institute of Technology, Stockholm, Sweden \\ ${ }^{2}$ Adam Mickiewicz University, Poznań, Poland \\ ${ }^{3}$ VU University Amsterdam, The Netherlands \\ ${ }^{4}$ Hokkai-Gakuen University Sapporo, Japan
}

Manuscript received: June 12, 2015

Revised version: January 7, 2016

Kourtit K., NiJKAmp P., SuZUKi S., 2016. New urban economic agents: A comparative analysis of high-performance new entrepreneurs. Quaestiones Geographicae 35(4), Bogucki Wydawnictwo Naukowe, Poznań, pp. 5-22, 3 figs, 1 table.

\begin{abstract}
Aвstract. Migrants are often the carriers of new skills and original abilities. This study focuses on the importance of 'new urban entrepreneurship' - in particular, ethnic or migrant business firms - as a major driver of creative and urban dynamics and economic vitality in urban agglomerations. The paper offers a general account of both backgrounds and socio-economic implications of migrant entrepreneurship in large agglomerations and highlights the socio-economic heterogeneity in motivation and performance among different groups of migrant entrepreneurs. This demographic-cultural diversity prompts intriguing questions about differences in business performance among distinct groups of migrant entrepreneurs, even in the same ethnic group. In the paper, a recently developed and amended version of data envelopment analysis (DEA), viz. super-efficiency, is presented and applied to a group of Moroccan entrepreneurs in four large cities in the Netherlands. The main research aim is (i) to identify the best-performing firms (so-called 'entrepreneurial heroes') from a broad management and business perspective, while (ii) the background of our findings are more thoroughly analysed. The paper ends with some general concluding remarks on urban business strategies.
\end{abstract}

KEY WORDS: economic vitality, urban development, entrepreneurship, migrant entrepreneurs, diversity, global diaspora economy, economic spillovers

Corresponding author: Karima Kourtit, KTH Royal Institute of Technology, School of Architecture and the Built Environment (ABE), Division of Urban and Regional Studies, Drottning Kristinas väg, 3010044 Stockholm, Sweden;

e-mail:karima.kourtit@abe.kth.se

\section{Setting the scene: the homo mobilis}

We live in an era of foreign migration, characterised by the emergence of the 'homo mobilis'. Millions of people leave their home country annually in order to find a better fortune somewhere else. This mega-trend will most likely not come to a standstill in the foreseeable future. Open cross-border communication, global access to information about other countries and cultures, rising international orientation and mobility, and advancing social and economic globalisation have paved the road towards a geographical shift in human capital unprecedented in the history of our world (for more information see also Nijkamp et al. 2012). Clearly, migration is not an exclusive feature of our century, but the extent and nature of migrant flows are clearly distinct from previous periods. Apart from the global background of contemporary migration 
- in contrast to the mainly regional orientation of foreign migration in the past centuries - modern migration centres largely on the acquisition and use of human capital, often of a high-skilled and innovative nature. From that perspective, international migration has turned into a new vehicle for spreading ideas, knowledge and skills. The 'homo mobilis' is the carrier of creative concepts and abilities that favour recipient areas.

The mega-trend described above is reflected in massive structural migration flows from and into many regions of the world, leading to a 'global diaspora economy'. Over the past few decades, cross-border migration has turned into a puzzling pattern of complex socio-economic, cultural and political developments in an interconnected global system (see Gorter et al. 1998; Sassen, Thielemann 2005; Zimmermann 2005). Nowadays, several scholars argue that especially the international migration of highly skilled workers is a vehicle to enhance global socio-economic and business efficiency (see e.g. Gheasi et al. 2013). The socio-economic profile of the current migrant volumes is often rather different from that of the host population in terms of demographic, cultural and entrepreneurial attributes. Worldwide, migrant settlement tends to be concentrated in specific geographical magnets (or attraction poles), in particular in the metropolitan agglomerations of the developed world (Longhi et al. 2010; Kourtit, Nijkamp 2012). It is of course important to know whether foreign migrants have a positive or negative long-range impact on the local, regional or national economy; their - in-groups and between-groups - diversity may lead to vast differences in the economic migration impact. It is noteworthy that the impact of the heterogeneity in motivation and behaviour among migrants is a challenging question (Nijkamp et al. 2012).

Clearly, migrants are by no means a uniform species. They are characterised by a great diversity and heterogeneity regarding skills, age, gender, income, wealth, cultural background, ethnicity, and motivation. Consequently, we observe not only geographically diverse patterns of migrant concentration (e.g., segregation), but also considerable differences in the geographical socio-economic impact of foreign migrants on the urban economy. Over the past years, the study of the 'new geography of migration' has brought about a wealth of new insights into the socio-economic and spatial effects of migrants on the host economy, in particular regarding local/regional labour markets and local self-employment. Empirical research has shown that it is not easy to obtain an unambiguous answer to the question of whether foreign migration serves the interest of host countries or regions. Various quantitative research methods have been developed in order to provide an evidence-based picture of the multi-faceted effects of migration on national or regional welfare, or on local labour markets (on the latter issue, see e.g. Greenwood et al. 1996; Longhi et al. 2005a, 2005b, 2008; Okkerse 2008; Nijkamp et al. 2012).

In this context, there is a growing strand of literature arguing that migrants may create new and untapped opportunities for the local economy. This appealing idea needs to be tested, however; it calls for a challenging research approach in order to make an empirically valid estimation of system-wide socio-economic consequences of foreign migration, both nationally and locally. The recently developed concept of 'migration impact assessment' (MIA) may be an important analytical vehicle to enable a systematic assessment of the pros and cons of international migration (Nijkamp et al. 2012).

An empirical estimation of the immigration impact on local host economies certainly deserves attention in the contemporary spatial-economic research in the Western world. These effects often appear to be located in urban areas. The extent to which immigration induces creativity, innovation and technological change is an emerging topic in the present-day immigration literature that attracts much attention of both researchers and policymakers. This can be illustrated, inter alia, by the current interest in migrant entrepreneurship, sometimes referred to as 'new entrepreneurship' (Dana 2007; Kourtit, Nijkamp 2011a; Sahin 2012). In many urban agglomerations or urban districts this type of self-employment seems to provide a vital and creative contribution to a flourishing urban economy and may enhance the participation of sometimes marginalised groups in the labour force (see also Razin, Light 1998).

The spatial transfer of skills - combined with migrants' knowledge about the host country - has become a major focal point in the current 
research and policy on foreign migration. This synergy of different competences may create significant positive externalities for the business sector - local or national - in the country or region of destination. Such advantages can be generated along two different channels:

- A cultural diversity channel, which brings together people from different ethnic or cultural origins, with complementary skills and competences, so that considerable productivity gains can be achieved through socio-cultural interaction among employees in business firms. This channel is in particular based on the assumption that a culturally diverse workforce will favour innovation and creativity (the knowledge spillover hypothesis; cf. Cohen, Levinthal 1989). Various studies have tried to quantify and test the cultural diversity hypothesis (e.g. Nijkamp, Poot 2013; Ozgen et al. 2011; Ozgen 2013; Suedekum et al. 2009).

- A migrant entrepreneurship channel, which originates in the fact that migrants in the host country can be forced to take lower-paid jobs due to language or educational deficiencies. To reach a higher place on the economic or career ladder, they will be strongly encouraged to be self-employed and/or to start their own business. In the past decades migrant entrepreneurship has become a prominent feature of major urban agglomerations in many host countries. An avalanche of conceptual and applied research contributions have recently been published, far too many to be summarised in this article. For extensive reviews we refer to Dana (2007), Nijkamp et al. (2012), and Sahin (2012), which offer a wealth of systematic ideas, research findings and relevant literature references.

The present study will focus in particular on the second channel, i.e. migrant entrepreneurship. It takes for granted that urban economies in large cities in the developed world act as magnets, not only for traditional low-skilled migrants, but increasingly also for economic opportunity seekers, in the form of skilled migrant entrepreneurs (Mitra 2012). In general, migrant entrepreneurship refers to business activities undertaken by migrants from a specific socio-cultural and ethnic background (Choenni 1997). Migrant entrepreneurs seek to enter the complex ramifications of large population concentrations, with the aim to identify and explore interesting new market niches (ranging from ethnic products to cheap mass products). They create significant socio-economic benefits from a new cultural diversity in the city as a result of foreign migration. Many of those migrant entrepreneurs come from different cultural, language or ethnic backgrounds. They have to survive under sometimes highly competitive conditions, using different business strategies (see also Aldrich, Waldinger 1999, and Van Delft et al. 2000).

Ethnic (or migrant) entrepreneurs not only have a significant impact on the local or district economy, but they may also be a positive stimulus for advanced and creative business making in modern cities all over the world. An analysis of the heterogeneity of local migrant entrepreneurship from different backgrounds forms the core research challenge of the present paper. There is a wealth of both general and case-study literature on economic achievements of migrant business firms (Dana 2007), but in many cases such firms are treated as a rather homogeneous group or species. With this background in mind, the present study seeks to assess differences in business performance among distinct classes of migrant entrepreneurs in order to trace driving forces of differences in performance. Such differences can be ascribed to specific skills, attitudes or behaviours (e.g. risk taking) of migrants (the human capital factor) or to favourable urban socio-environmental (or contextual) conditions in the form of social bonds, networking, market densities, or community support (the 'social urban embeddedness' framework; see e.g. Kloosterman, Rath 2003). After a review of motives and socio-economic aspects of migrant entrepreneurship and of the urban constellation of this new type of entrepreneurship, attention will focus on salient differences in the business performance of groups of distinct migrant entrepreneurs. On the basis of data from a detailed survey among ethnic entrepreneurs in four large Dutch cities, a recently developed type of data envelopment analysis (DEA) is presented and applied as an appropriate analytical tool to trace differences in business performance between specific groups of migrant entrepreneurs. The paper will conclude with some retrospective and prospective remarks. 


\section{Migrant entrepreneurship: diversity in motives}

Migrant entrepreneurship has assumed a prominent place in modern urban business activities and is well documented in early literature since the 1980s (we refer here, e.g., to Hardin 1974a,b; Ward, Jenkins 1984; Min 1987; Waldinger et al. 1990; van Delft et al. 2000; Masurel et al. 2002; Kloosterman, Rath 2003). In the past, self-employment was often prompted by the need for economic survival for immigrants and ethnic minority groups, known as 'lifeboat economics' (see Garrett Hardin's Lifeboat ethics 1974a,b). Historically, migrants had often a specific and isolated position - 'a stranger was a trader' (a survival strategy to ensure financial independence, while improving their working conditions and escaping from discrimination and stigmatisation). Nowadays, we observe an overwhelming presence of specific migrant groups in the regional and local economies of many host countries all over the world.

This 'new entrepreneurship' - distinct from 'normal' entrepreneurship - started originally by an orientation towards migrant products and services ('ethnic goods'), migrant market customers, or indigenous or traditional migrant business growth strategies (Choenni 1997; Masurel et al. 2002, 2003; Rusinovic 2006; Sahin et al. 2007; Kourtit, Nijkamp 2012). A wealth of recent research has addressed opportunities for and barriers to successful migrant entrepreneurship. According to Sahin (2012), some scholars advocate a culturalist approach by claiming that migrant groups have specific values, skills and cultural features that make them suitable for entrepreneurship, while others argue that the socio-cultural situation in the host country or in the local economy prompts the need for resorting to entrepreneurial activities. Social exclusion and discrimination, poor access to markets, or high levels of unemployment are examples of the latter structuralist response factors (Sahin et al. 2007). In this context, Chaganti and Greene (2002) distinguish three categories of migrant businessmen: (i) immigrant entrepreneurs: individuals forced to start their own business as a strategic economic survival; (ii) migrant entrepreneurs: migrants who share socio-cultural connections and common patterns of interaction, often based on a common national background or common migration experiences (Waldinger et al. 1990); and (iii) minority entrepreneurs: business owners belonging to ethnic groups that do not represent the majority of the population. It should be added that in recent years a gradual transition has taken place in the profile of migrant entrepreneurs, especially those belonging to the second generation of migrants. Traditional motives (such as social exclusion or a weak position on the labour market) are gradually replaced by mainstream entrepreneurial motives (profit making, social esteem).

Clearly, migrants may have different motives for engaging in entrepreneurship. Examples of various explanatory models for the choice of entrepreneurship are: (i) the economic opportunity model; (ii) the culture model; and (iii) the reaction model (Sahin 2012). The economic opportunity model assumes that migrant minority businesses rely on market chances for their economic fortunes. The culture model takes for granted that some cultures predispose group members to the successful implementation of entrepreneurial goals, while the reaction model takes for granted that self-employment amongst members of migrant minority groups is a socio-economic response to racism and to barriers in mobility. Furthermore, according to Waldinger et al. (1990), migrant minority businesses tend to originate from the interplay of opportunity structures, group features and business strategies in adapting to the local environment. Many migrants appear to prefer benefits of the independence of (risky) entrepreneurship to having a low-paid job at the bottom of the labour-market ladder. By starting up a new enterprise, migrants want to increase their income and climb up the social ladder of an urban economy.

It should be noted that there can be a multiplicity of other reasons for migrants to engage in entrepreneurship, for instance, to be independent, to earn a higher income, to gain new work experience, or to have a more flexible lifestyle. Those motives have been extensively addressed by Masurel et al. (2002, 2003), Sahin et al. (2007) and Kourtit and Nijkamp (2011b). On the basis of empirical evidence, Brush (1992), Fagenson (1993), Fischer et al. (1993), Kloosterman et al. (1999), Kloosterman and Rath (2003) and Sahin 
et al. (2007) identified individual characteristics of migrant entrepreneurs in a local economy, in particular, demographic features, personal motivation, or specific educational or occupational experience as entrepreneurs. Their research demonstrated that there were significant differences in their work experience, skills, business goals and management styles. Sahin (2012) identified the most prominent personal characteristics of migrant entrepreneurs: a lower education level, a less-favoured socio-economic position, and a generally low level of access to the labour market. They also share various common problems in starting or performing their businesses, in particular administrative and regulatory barriers, lack of capital and credit, lack of knowledge, inadequate command of the language, lack of appropriate education, lack of management skills, constraints on access to formal business networks, and migrant discrimination (Sahin et al. 2007). These studies thus demonstrate the existence of a variety of motives in migrant entrepreneurship. This heterogeneity will probably have a significant impact on economic performance, which will be further investigated in the present study.

The behaviour and economic position of migrant entrepreneurs has been studied extensively in many countries (see Sahin 2012 for a description of several such studies). But a very important question is whether migrant entrepreneurs are a uniform species whose business performance is largely identical in a competitive environment, or whether differences in their socio-cultural backgrounds and in indigenous features are also reflected in differences in attitudes and behaviour, and consequently in their business performance. Even though such migrants can be driven by similar motives (e.g. profit maximisation or economic advancement), they can have different skills, attitudes or risk-taking perception, which are decisive for their economic success. On top of it, also the socio-urban constellation in which they operate often shows a great variety, so that it may seem plausible that migrant diversity may mirror differences in economic performance of migrant business firms. Recent research (Sahin et al. 2010, 2012; Kourtit, Nijkamp 2012) shows that nowadays the younger generation of entrepreneurs tends to be higher educated and better integrated with the local community. Through their human capital, motivation and driving forces, they have improved their ability to become involved in new areas of business activity. They tend to be more outward looking for new opportunities outside traditional markets and products (economic expansion and business growth strategies; see Ansoff 1957). They also look for appropriate break-out strategies (Engelen 2001), by offering high-quality products and services to a broader market niche, outside their own indigenous ethnic group. Furthermore, they are more inclined to use support systems such as capital and information sources, in order to be more independent of their family, friends and social bonds. Thus, this 'new entrepreneurship' creates interesting possibilities for employment at a time when it is difficult for ethnic groups to find jobs (Dagevos, Gesthuizen 2005; Kourtit et al. 2013a; Masurel et al. 2002).

An important implication following from the above concise and selective tour d'horizon is that migrants' capacities and resources probably matter - and their ethnicity probably less so - in achieving different degrees of business performance and success. Given the variety of motivation and background conditions of migrant entrepreneurs, it seems plausible to hypothesise that their economic performance will also show considerable diversity. This heterogeneity in the performance of migrant entrepreneurs will be further tested in the present study. We will first pay attention to location factors determining the development of migrant entrepreneurship.

\section{Migrant entrepreneurship: socio- economic diversity in cities}

Urban agglomerations all over the world increasingly tend to become magnets for new socio-economic opportunities. The urban economy offers ample opportunities for a variety of job seekers and self-employed, not only for lowskilled segments of the labour market, but also of higher-skilled segments. Job diversity, a large job market, contact density, and a multiplicity of communication channels facilitate human interaction and responses in the urban space. Such conditions provide a great socio-economic potential for migrants, a reason why modern cities exert a centripetal influence on foreign migrants. From this perspective, the emergence of migrant 
entrepreneurship in many large cities is a logical development.

In the recent years, migrant (or ethnic) entrepreneurs - as mentioned above - have become a fascinating complement to the traditional urban space economy. Cultural diversity is nowadays often seen as an increasingly valued positive developmental factor, and its social, cultural and economic benefits are broadly recognised (for a review see Sahin 2012). Over the past decades, cultural diversity has turned into a signpost for modern urban society. Several European countries have become host regions for foreign migrants, be it for the purposes of work or a family reunion. Many of them appear to be more risk-oriented than natives. In addition, barriers in obtaining work has induced many migrants to set up their own businesses. Their spatial preference for urban agglomerations and their business strategy to provide specific ethnic products or services have often led to a flourishing business life in those cities. This has, of course, increased the initial market size of migrant entrepreneurship within the ethnic community itself, thus prompting new urban dynamics.

It has been argued in the literature that the decision to become self-employed differs usually between immigrants and native people (Borjas 1986; Fairlie, Meyer 1996). In particular, education and duration of stay are important drivers of self-employment (Fairlie, Meyer 1996). Nowadays, the emerging 'new entrepreneurship' is highly important for the socio-economic and urban development of Europe (Audretsch 2002). Migrant entrepreneurs often start promising but high-risk activities in sectors where other people see fewer opportunities.

Several migrant groups appear to have become a highly creative and qualified entrepreneurial class in urban business life. The market size and dynamic opportunities in the urban economy clearly create seedbeds for many new business opportunities, e.g., fast economic growth, upscaling of the labour force, and exploitation of new market niches (see also Sahin 2012). And consequently, dynamic urban agglomerations are a magnet 'par excellence' for new forms of creative entrepreneurship. Especially the sector of small and medium-sized enterprises (SMEs) seems to comprise an increasing share of migrant entrepreneurs originating from many countries and involved in many branches of the urban economy (e.g. catering, cleaning, taxi services, but also increasingly high-tech services, consultancy, etc.). Migrant entrepreneurs thus tend to bring vitality to the urban business sector, where traditional or incumbent firms are sometimes no longer able to survive (see also Jacobs 1961, 1969; Light, Gold 2000). In particular, the new generation of young migrants engages more than ever before in education, business and the high-skilled urban workforce (Cormack, Niessen 2002). Clearly, successful self-employed migrants or migrant business firms contribute to a better socio-economic symbiosis of modern urban society.

The fascinating urban socio-economic dimensions of 'new entrepreneurship' have increasingly prompted much research, also in a European context. Earlier studies of migrant entrepreneurship focused preponderantly on the USA (Light 1972; Waldinger et al. 1990), while later studies also embraced Western Europe (Chaganti, Greene 2002; Masurel et al. 2002; Fairlie 2004, 2005; Sahin et al. 2007, 2010, 2012; Kourtit, Nijkamp 2011a, 2012). Several works also address critical success or performance conditions for migrant entrepreneurs (van Delft et al. 2000; Zhou 2004). They examine in particular structural factors, cultural factors, or a blend of them (included, inter alia, in the interaction model formulated by Waldinger et al. 1990) that were decisive for the step towards new forms of migrant business in cities.

The socio-economic consequences of migrant entrepreneurship are clearly reflected in local and regional labour markets (see e.g. Masurel et al. 2002; Longhi et al. 2010; Kahanec, Zimmermann 2011); in public finance systems (Hodgson, Poot 2011); in international trade (Genc et al. 2012); and - as indicated in the present study - in business innovation and entrepreneurship (Ozgen et al. 2011; Sahin et al. 2012). Clearly, a thorough, operational and comprehensive analysis of the manifold entrepreneurial consequences of foreign migration is needed (Hodgson, Poot 2011; Kourtit, Nijkamp 2011; Nijkamp et al. 2012). Consequently, as argued above, migration impact assessment (MIA) may have to be positioned in the broader context of cultural diversity and business performance (Fearon 2003; Ottaviano, Peri 2006; Constant, Zimmermann 2008; Kourtit, Nijkamp 2012). 
In conclusion, urban migrant entrepreneurship is a multi-faceted phenomenon that reflects the great socio-economic diversity of business life in modern cities. It is therefore important to investigate in more detail differences in business performance within this important group of urban economic agents. This will be undertaken in the following sections by means of a new type of performance analysis, coined Data Envelopment Analysis (DEA), carried out in a group of migrant entrepreneurs in Dutch urban areas.

\section{Empirical database and methodology}

The present study aims to identify differences in economic performance among migrant entrepreneurs, and not differences between native and migrant entrepreneurs. Migrant entrepreneurs operate traditionally in specific niche markets (e.g. ethnic products) in which native entrepreneurs are less active; hence, a comparison between those groups is less meaningful. This section describes our database and the methodology employed. Our empirical approach is based on a unique, extensive and detailed micro-information base - obtained through empirical fieldwork - on the characteristics of mainly new-generation (or migrant) entrepreneurs of Moroccan origin, mostly in the high-tech and creative industries in Dutch cities. Many migrant entrepreneurship studies address members of the first generation, who are more concentrated in the traditional sectors (e.g. the clothing, hotelling, catering and cleaning sectors). More recently, we observe ever more attention paid to migrant entrepreneurship in non-traditional sectors - in particular, the creative industries - increasingly interesting to second-generation entrepreneurs.

An analysis of new trends in ethnic/migrant entrepreneurship and its growth strategies (see the conceptual framework described in Ansoff's (1957) business growth theory) highlights the fact that second-generation migrant entrepreneurs in the creative sector focus more on an external market orientation ('break-out strategies'; see also Engelen 2001), in contrast to traditional sectors, in which the first generation of migrant entrepreneurs is often engaged. Their goal is to expand their market domain by means of 'breakout strategies', by offering high-quality and innovative goods to a broader group of clients and markets outside their own ethnic group (see also Kourtit, Nijkamp 2012; Kourtit et al. 2013a).

Out of the three largest ethnic groups in the Netherlands, Moroccan entrepreneurs show the sharpest absolute rise of all non-Western entrepreneurs. They have a relatively high birth rate, engage in interesting new markets, and provide a positive stimulus to creative and new forms of business making in Dutch cities. They can also make a critical contribution to the improvement of the social climate of a specific neighbourhood. Therefore, it is interesting to focus on critical success factors of those migrant business firms. Our empirical work embraced mainly higher-educated young Moroccan entrepreneurs in mostly high-tech and innovative sectors in the four largest Dutch cities: Amsterdam, Rotterdam, the Hague, and Utrecht, which all have a rich variety of migrant entrepreneurs. These urban agglomerations have turned into multicultural 'melting pots' made up of people of different cultures, races and religions (Jacobs 1961, 1969).

The purpose of our empirical research was to explore and trace the motives, opportunities and barriers of those ethnic entrepreneurs and critical success conditions of the highest-performing ethnic firms ('business champions') in the innovative and creative sector, while making a distinction between the high and low performance of those ethnic firms in Dutch cities. Since the collection of individual data on the business performance of migrants (including financial information) is extremely hard, detailed databases on migrant entrepreneurs' success are extraordinarily hard to obtain, so that normally we are forced to work with limited sample material, which brings the research close to a comparative case study, popular rather in business administration and industrial organisation.

To identify those opportunities and barriers, and to achieve a better understanding of drivers of entrepreneurial behaviour and performance of the second-generation ethnic entrepreneurs of Moroccan origin in Dutch cities - with a focus on their personal and business characteristics as well as their motivation and driving forces - we employed and organised an extensive in-depth field survey (a 'self-composed statement questionnaire') in our search for such 'entrepreneurial heroes' or 'business champions' with a peak 
business performance ${ }^{1}$. Our entrepreneurship database is based on this questionnaire, which was administered on the basis of a sample of 24 ethnic entrepreneurs of Moroccan origin (20082009). They were selected from a group of skilled and innovative ethnic entrepreneurs in the sector of business-related professional services, who distinguish themselves from their traditional ethnic niche by offering new products or services and by using modern communication channels. This is clearly a relatively small sample, but in this emerging new market it turned out to be extremely difficult to find more second-generation entrepreneurs willing to participate in such an in-depth and time-consuming interview with many privacy-sensitive issues. It turned out that this group size was reasonably sufficient, as after more than 20 in-depth interviews the level of new information obtained and new insights went rapidly down.

Our analytical framework aims to depict the various forces that influence the firms' performance. Individual firm data are related to both output and input performance characteristics, as well as to the motivational and driving forces decisive for turning a firm into a high-performance entity which we can call an 'entrepreneurial hero' or a 'business champion', taking into consideration all relevant aspects of its business structure.

In our research, we use the original micro-data, containing more than 35 indicators, with detailed information about a firm's characteristics and critical factors that exert a decisive impact on its performance. Those critical success factors (CSFs), which essentially represent a high-performance systemic perspective, are conceptually summarised in the pentagon model shown in Fig. 1 (see also Nijkamp, Pepping 2007; Akgün et al. 2011). Individual firms' data are organised according to this model.

This model presents critical drivers of the business performance of migrant firms, mainly in the innovative or creative sector. This systemic strategic framework is based on detailed assessments and evaluations of performance determinants of the migrant firms concerned, grouped into five key factors incorporated into the model in Fig. 1. This model is a systemic approach that involves a balanced set of original, promising and integrated

This survey was part of the so-called SUS-DIV project.
CSFs and conditions that can lead to effective action for maximising business performance (output). The five main key performance factors and their detailed breakdown are as follows:

- Factor 1, human capital (HC), consists of variables (e.g., education level, Dutch language proficiency, duration of stay, reason to start up a business) that refer to the quality of labour input obtained by means of education, training or new skills (e.g. in ICT) and may be seen as a productivity-enhancing factor (see also Sjaastad 1962). Clearly, the distribution of human capital among people is of critical importance, while the availability of productive capital (PC) also plays an important role, similar to neo-classical production theory in which the output is determined by the traditional production factors: labour and capital.

- Factor 2, social capital (SC), contains contextual conditions (e.g. network participation, support from the social network) that comprise interaction and communication between people and firms, socio-economic bonds, social support systems, business networks (formal and informal), relations based on trust, and so forth (see e.g. Kloosterman et al. 1998). This factor represents drivers that create a socially sustainable society, in particular (see also Nijkamp 2008):

- creativity (a potential human asset that forms the foundation of innovative ideas);

- diversity (a systemic notion that supports open-mindedness, coping with stress, etc.);

- accessibility and connectivity (by exploiting the hub character of a city for business opportunities in a worldwide competitive setting).

- Factor 3, creative capital (CC) and knowledge capital $(K C)$, refers to variables (e.g. years of existence of a firm, previous qualifications, business plans for the start, use of information sources, diversity of employees) that indicate a great ability to cope with challenges and new opportunities, reflected in entrepreneurial spirit, new ways of thinking and acting, trend-setting artistic expressions, innovative foresight, etc. These factors are often found in a multicultural urban 'melting pot'.

- Factor 4, financial capital (FC), consists of variables (e.g. size of capital source, financial support) that refer to the financial basis necessary 
for the efficient operation of a business-oriented urban area (Dubini 1989). In particular, two forces are relevant here (see also Nijkamp 2008):

- open competition among many actors (to induce a creative search for new decisions and courses of action);

- entrepreneurship in business life (to stimulate innovativeness).

- Factor 5, entrepreneurial capital (EC), contains various variables (e.g. start-up situation of a firm, extent of start-up problems, economic situation of the sector, extent of attractive market, diversity in customs or habits, marketing efforts, managerial and operational support, degree of strategic vision) that reflect business drivers of the firm concerned, in the spirit of earlier contributions to business management such as the need for achievement and desire for independence drivers (Maslow 1943, 1954; McClelland 1953; Schere 1982; Shane et al. 2003), risk-taking propensity (Ansoff 1957; Brockhaus 1980), and access to new markets: a 'break-out strategy' (Waldinger 1986; Engelen 2001).

The five main constituents of the model in Fig. 1 should not be viewed in isolation, but form an interconnected set of inputs in a performance system in which a firm's development strategies, skills for making the right strategic decisions, and the integration of available inputs into its daily strategy are extremely important for its future strategic planning. Clearly, an imbalance in the pentagon prism of Fig. 1 may mean a threat to and may have a negative impact on the performance of all activities involved. Clearly, any business success in a competitive economic system is driven by profit motives, but the underlying constituents should be balanced against each other, as they are also mutually connected. Linking together those five areas in an interactive chain is an essential challenge for each firm, and will have a positive impact on its performance, particularly as this brings it potential benefits from efficiency and competitiveness. Furthermore, a positive performance of a firm (business) will bring about positive socio-economic results for cities and regions.

Before pursuing a further statistical analysis of Fig. 1 in order to offer a comprehensive quantitative estimation of high-performing firms, so-called 'entrepreneurial heroes' or 'business champions', we first present a novel approach to assessing business performance based on data

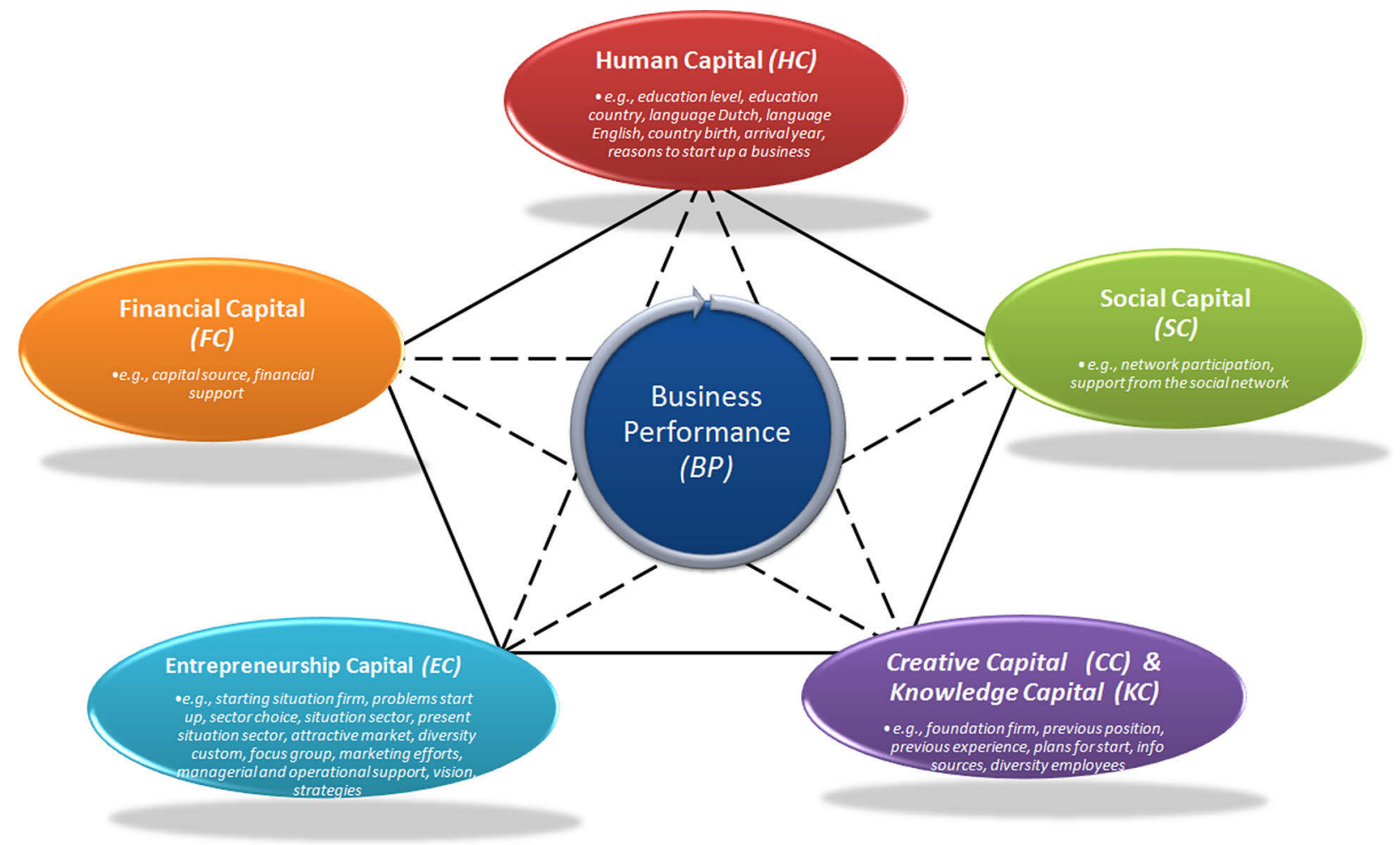

Fig. 1. Model of the complex field of force of business performance. 
envelopment analysis (DEA) in order to judge in an appropriate way the comparative achievement of those ethnic firms. The aim of DEA is to obtain comparative insights into the relative efficiency of a firm compared with other firms.

\section{Data envelopment analysis (DEA): new roads ${ }^{2}$}

\section{The standard DEA model}

A wealth of literature in the field of industrial organisation has been published on quantitative benchmark analyses of the performance of rather similar business organisations in a given economic activity. The measurement of economic performance is essentially based on the ratio between a set of output factors (e.g. products, profits, jobs) and a set of input factors (e.g. production factors, capital use, etc.). Thus, the performance of a business firm is essentially a generalised productivity or efficiency measure. This is extensively covered in the abundant DEA literature.

In this section, we outline some essential steps of our DEA experiment, starting from a standard DEA tool and then moving forward to a super-efficient DEA using a recently developed technique, viz. a distance friction minimisation (DFM) method. The standard model developed by Charnes, Cooper and Rhodes (1978) for a given decision-making unit (DMU) - abbreviated to the CCR model - aims to assess the relative performance of a DMU relative to the performance of other DMUs. DEA is a deterministic multi-objective programming technique able to cope with multiple input and output objectives. It has found wide application in the industrial organisation literature, and can be regarded as a sort of benchmark analysis that judges the multidimensional efficiency of the operation of a DMU in comparison with other DMUs. Whether a DMU is efficient or inefficient depends on whether or not it is located on the efficiency frontier of all

\footnotetext{
Various technicalities in this paper display close similarities with another article by two of the co-authors (Suzuki, Nijkamp 2011), which was developed in parallel at the time of the publication of the present article. These similarities pertain only to the methodology and not the application, which is novel and path breaking. Proper credit must be given to this earlier publication.
}

the DMUs together (the set of all possible maximum achievement levels). DMUs on the efficiency frontier have an efficiency score of 1 , while less efficient DMUs have a lower score, depending on their distance from the efficiency frontier.

DEA has become an established method in the recent management literature as a tool for benchmarking and performance management, and a myriad of applications can be found in the literature (for an overview, see Anderson, Petersen 1993; Seiford, Zhu 2003). It has also been applied several times in the regional and urban field (Macmillan 1986; Athanassopoulos, Karkazis 1997; Maudos et al. 2000; Zhu 2001; Afonso, Fernandes 2006; Halkos, Tzeremes 2010; Suzuki et al. 2010, 2011; Kourtit et al. 2011a, b; Kourtit et al. 2013a, b). It will now be used in our study as a quantitative tool to assess the business performance of a set of individual migrant entrepreneurs. The sample of firms used in our study is not very large, but this is rather common in DEA practice, as the collection of detailed data is costly. Representativeness is less important than the presence of comparable agents. For that reason, DEA - as a deterministic comparison technique of DMUs with some similar features - is different from stochastic regression methods based on samples of larger sizes. Furthermore, in a given market niche with a limited number of suppliers, there is often no need for an extension of the database.

\section{A new DEA based on distance friction minimisation (DFM)}

As mentioned above, the efficiency improvement solution in the original DEA model is based on the assumption that in the efficiency frontier map the input values are reduced radially at a uniform rate. Recently, a new generalised distance friction has been developed to assist a DMU to improve its efficiency by a movement towards the efficiency frontier surface. The direction of efficiency improvement depends, of course, on the input/output data characteristics of the DMU. This relatively new approach defines projection functions for the minimisation of distance friction by using a Euclidean distance in weighted spaces. This forms the key aspects of the distance friction minimisation (DFM) model. Thus, the DFM approach generates a new contribution 
to efficiency enhancement problems in decision analysis by employing a weighted Euclidean projection function and, at the same time, it can address both input reduction and output increase (for more technical details see Nijkamp, Suzuki 2009; Suzuki, Nijkamp 2011; Suzuki et al. 2010, 2011; Kourtit et al. 2013a, b).

We will not provide a detailed description of the various steps involved in the DEA model, but the details can be found in Nijkamp and Suzuki (2009); Suzuki and Nijkamp (2011); Suzuki et al. (2010, 2011); and Kourtit et al. (2013a,b). This more satisfactory and sophisticated approach will be used in our analysis. By means of the DFM model, it is possible to present a more appropriate efficiency improvement solution than the standard CCR projection. This means that by the application of DFM there is an increase in new options for efficiency improvement solutions in DEA. The main advantage of the DFM model following from DFM application is that it yields an outcome on the efficiency frontier that is as close as possible to the DMU's input and output profile.

\section{The super-efficiency model}

As mentioned earlier, in a DEA model efficient DMUs have an identical score 1 . The existence of equal scores of 1 for all the efficient DMUs does not allow us to discriminate further among them. This unsatisfactory assessment of efficient DMUs in a standard DEA model - in which all efficient firms obtain an equal ranking - has prompted a new research to discriminate between efficient DMUs, in order to arrive at a ranking - or even a numerical rating - of those efficient firms, without, however, affecting the results for DMUs with a given degree of inefficiency. Anderson and Petersen (1993) develop a radial super-efficiency model, while Tone's $(2002,2003)$ later work designs a so-called slacks-based measure of super-efficiency in DEA. In general, the super-efficiency model seeks to identify the relative importance of each individual efficient DMU by designing and measuring a score for its 'degree of influence' when this efficient firm is omitted from the frontier of an efficient production possibility. If this elimination really matters (i.e. if the adjusted distance from this omitted DMU to the remaining efficiency frontier is great), and thus the DMU concerned has a high degree of influence and outperforms the other DMUs, it obtains a high score (and is thus super-efficient). It should be noted that the rating of non-efficient firms remains equal in this super-efficiency model.

Anderson and Petersen's (1993) super-efficiency model provides the possibility of ranking all efficient DMUs. Efficiency scores from their super-efficiency model are obtained by eliminating data on the DMU to be evaluated from the solution set. For the input model, this can result in values that may be regarded - according to the DMU concerned - as a state of super-efficiency. Those values are then used to rank the DMUs and, consequently, efficient DMUs may then obtain an efficiency score above 1 . The super-efficiency model can thus be suitable for finding the set of highest-performing firms for our comparative database on ethnic entrepreneurs.

In this way, for each individual DMU, a new distance result is obtained, which leads to a new ranking - and even a rating - of all the original efficient firms. Clearly, the main problem in super-efficiency DEA is how to define the distance between an efficient DMU and the production possibility set that emerges after the elimination of a single efficient DMU. In the literature, the slacks-based approach (Tone 2002, 2003) has been advocated. This method will also be applied in our empirical investigation of migrant firms in Dutch cities.

\section{A combined super-efficiency DFM model}

We can next design a super-efficiency DFM model integrated with the standard DEA model. In a normal DFM model, the input or output values obtained as an optimal solution result in a set of optimal weights for the DMU. Our new super-efficiency DFM model (henceforth SE-DFM) is now based on the idea that those optimal values result from the application of the super-efficiency model. The advantage of the SE-DFM model is that it yields an unambiguous and measurable outcome in a ranking of efficient DMUs, i.e. this new integrated model can be suitable for finding the highest-performing DMUs while retaining all the advantages of the DFM model. Therefore, ultimately, the SE-DFM model forms the basis of our analysis of the performance of migrant 
entrepreneurs in Dutch cities. This will be further empirically dealt with in the next section.

\section{In search of 'business champions'}

As mentioned above, we have extensive micro-based data on individual and contextual performance conditions of a set of Moroccan entrepreneurs in the Netherlands. Our empirical work focuses on higher-educated young Moroccan entrepreneurs in the high-tech and innovative sectors in the four largest Dutch cities. After a review of the needs, motives and socio-economic aspects of this new and colourful entrepreneurship, our attention will focus on interrelated determining factors that influence their business performance and the differences in this performance. This set of factors is at the core of our business performance model (see Fig. 1). The model encompasses all factors that are critical success drivers and conditions (as inputs) that can lead to effective action to maximise business performance measured in various dimensions. The scale of those firms does not differ significantly, so that a comparative analysis based on DEA is warranted. On the basis of our survey among those entrepreneurs in the four large Dutch cities and a subsequent multivariate data reduction method, first a standard DEA is applied in order to trace differences between those entrepreneurs. Next, we use the new technique of super-efficient DEA for individual firms in order to identify those 'business champions' that exhibit an extraordinary business performance.

\section{Efficiency scores for super-efficiency and CCR-I}

For any DEA exercise, all relevant input and output factors of all DMUs have to be included. In our study, for each firm we distinguish five input factors (see Fig. 1 again): human capital (HC), social capital (SC), creative (CC) and knowledge capital (KC), financial capital (FC), and entrepreneurial capital (EC), and four output factors: sales, profit, higher results, and quality. All this information originated from detailed face-to-face interviews with the entrepreneurs concerned. These data were included in the DEA analysis that forms the core analytical instrument in our study. The efficiency evaluation results for the 24 ethnic entrepreneurs based on the standard DEA model and the super-efficiency model using the five inputs and the four outputs are now given in Fig. 2. Clearly, given the large number of input factors - in comparison with the number of the DMUs - several DMUs with an efficiency score of 1.0 can be found. Therefore, this is an ideal case to test whether the application of the SE-DFM model leads to a more refined analysis and more interesting conclusions about the relative performance of those firms.

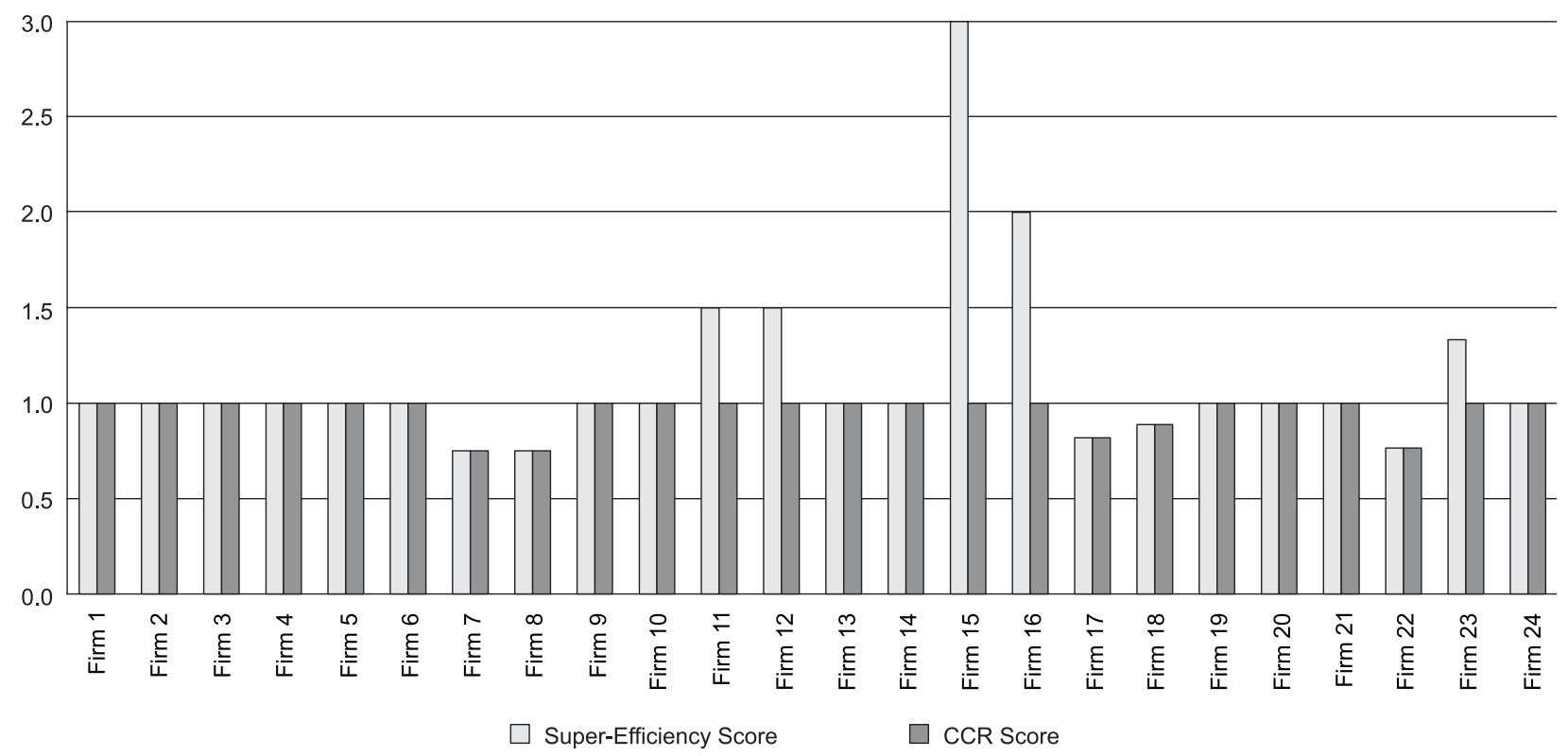

Fig. 2. Efficiency score based on the CCR model and the super-efficiency model. 
From Fig. 2, the ranking of the super-efficiency of 19 out of the 24 firms was established on the basis of their high super-efficiency score (efficient DMUs that obtained an efficiency score above 1). It is noteworthy that in our analysis Firm 15 is the 'business champion' in terms of the super-efficiency model. This is an unambiguous result that originates from the advantages of the design of this model. The next in the ranking is Firm 16, followed by Firms 11 and 12, and then Firm $23^{3}$. There seems to be no systematic variability in the performance of firms across cities.

\section{Efficiency-improving projection based on the SE and SE-DFM models}

The results of the efficiency improvement projection based on the SE and the SE-DFM model for inefficient firms are presented in Table 1. The SE projection shows that, for instance, Firm 18 - in order to achieve a super-efficiency state - should reduce its input volumes of SC, CC \& KC and EC by $11.1 \%$, HC by $14.8 \%$, and FC by $40.7 \%$, and increase its profit by $80.6 \%$ in order to become efficient. On the other hand, the SE-DFM projection results show that a reduction in the EC of $6.6 \%$ and an increase in the sales of $25.5 \%$ are required for a firm to become efficient. This is further illustrated in Fig. 3.

We will now illustrate our results using one firm in particular. Firm 18 focuses on non-traditional and fast-growing sectors, and operates in a volatile environment with continually changing technologies, markets and business strategies as well as shifting consumer needs for products and services, which differ widely at the national, regional and local levels (Boissevain et al. 1990) and offer (new) business and market opportunities at different geographical scales (Razin, Light 1998).

In running its business, this firm faced entrepreneurial problems that impeded its growth (sales) and success. Its main problems reported are: overregulation concerning, for instance, long delays in obtaining an approval for trade licences and business registration; the uncertain challenge of implementing unknown strategies and formulating goals; the bureaucratic need to maintain an accurate internal business process and administration; problems with attracting good and highly-skilled employees; and its limited access to financial capital (Kourtit, Nijkamp 2012).

Furthermore, in order to stay ahead and remain competitive under various conditions, this entrepreneur has to be very critical in its business

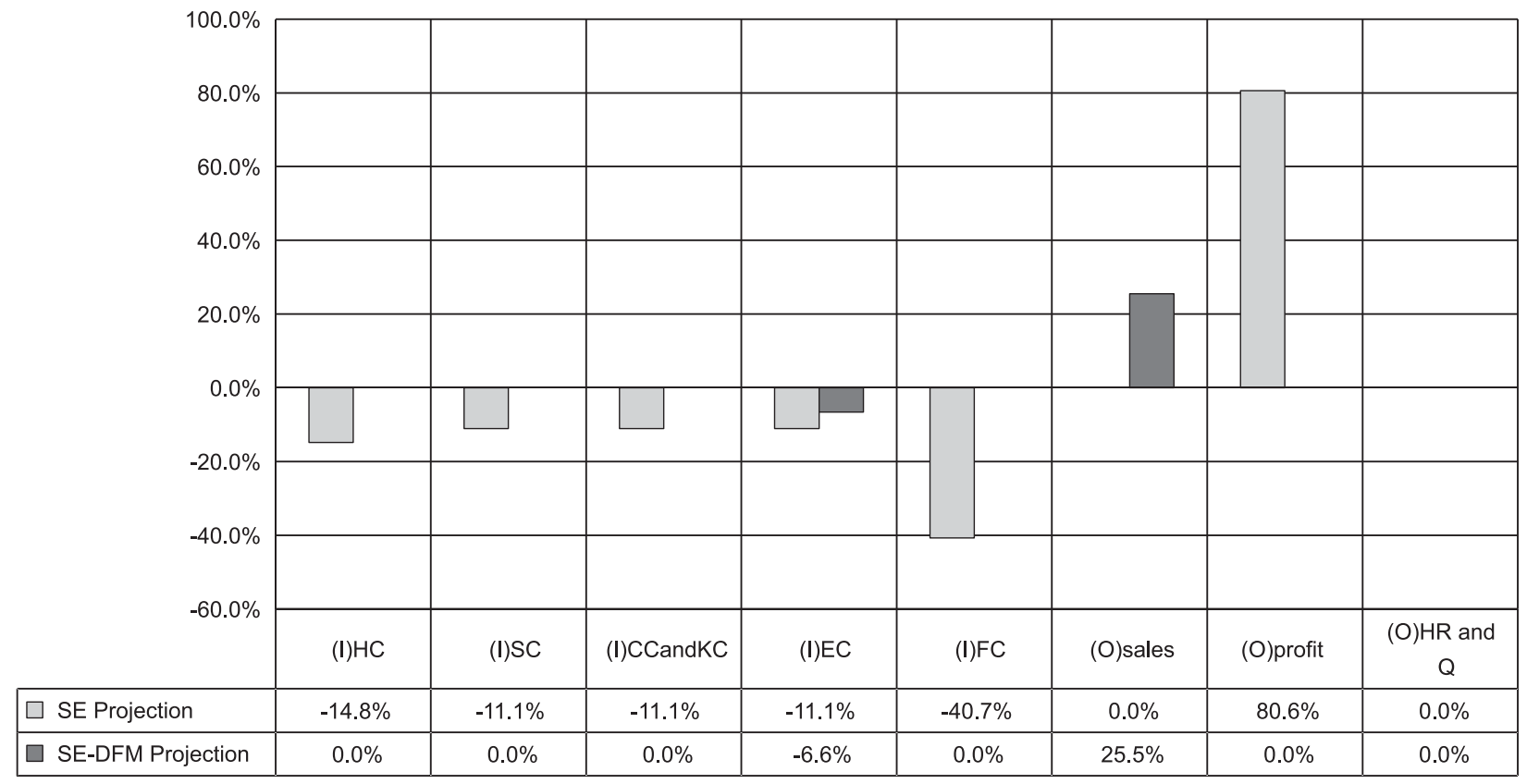

Fig. 3. Projection results of Firm 18, based on SE and SE-DFM.

3 For privacy reasons, the names and nature of those firms are not disclosed. 
Table 1. Efficiency-improvement projection of the SE and SE-DFM models.

\begin{tabular}{|c|c|c|c|c|c|c|c|c|c|c|c|}
\hline & \multirow{2}{*}{\multicolumn{2}{|c|}{ SE model }} & \multirow{2}{*}{\multicolumn{2}{|c|}{ SE-DFM model }} & & & \multirow{2}{*}{\multicolumn{2}{|c|}{ SE model }} & \multirow{2}{*}{\multicolumn{2}{|c|}{ SE-DFM model }} \\
\hline & & & & & & & & & & & \\
\hline DMU & Score & \multicolumn{2}{|c|}{ Score $\left(\theta^{* *}\right)$} & \multicolumn{2}{|c|}{ Score $\left(\theta^{* \star}\right)$} & DMU & Score & \multicolumn{2}{|c|}{ Score $\left(\theta^{* *}\right)$} & \multicolumn{2}{|c|}{ Score $\left(\theta^{* *}\right)$} \\
\hline I/O & Data & Difference & $\%$ & $\begin{array}{c}\text { Difference } \\
d_{i o}{ }^{x^{*}}-s^{-* *} \\
d_{r o}{ }^{y^{*}}+s^{+* *}\end{array}$ & $\%$ & I/O & Data & Difference & $\%$ & $\begin{array}{c}\text { Difference } \\
d_{i o}{ }^{x^{*}}-s^{-* *} \\
d_{r o}{ }^{y^{*}}+s^{+* *}\end{array}$ & $\%$ \\
\hline Firm 7 & 0.750 & \multicolumn{2}{|c|}{1.000} & \multicolumn{2}{|c|}{1.000} & Firm 18 & 0.889 & \multicolumn{2}{|c|}{1.000} & \multicolumn{2}{|c|}{1.000} \\
\hline (I)HC & 3.000 & -0.8 & $-25.0 \%$ & -0.7 & $-31.7 \%$ & (I)HC & 3.000 & -0.4 & $-14.8 \%$ & 0.0 & $0.0 \%$ \\
\hline (I)SC & 5.000 & -2.0 & $-40.0 \%$ & -1.6 & $-52.4 \%$ & (I)SC & 3.000 & -0.3 & $-11.1 \%$ & 0.0 & $0.0 \%$ \\
\hline (I)CCandKC & 4.000 & -2.0 & $-50.0 \%$ & -1.7 & $-85.7 \%$ & (I)CCandKC & 2.000 & -0.2 & $-11.1 \%$ & 0.0 & $0.0 \%$ \\
\hline (I)EC & 4.000 & -1.0 & $-25.0 \%$ & -0.6 & $-19.0 \%$ & (I)EC & 4.000 & -0.4 & $-11.1 \%$ & -0.2 & $-6.6 \%$ \\
\hline (I)FC & 4.000 & -3.0 & $-75.0 \%$ & -2.9 & $-285.7 \%$ & (I)FC & 3.000 & -1.2 & $-40.7 \%$ & 0.0 & $0.0 \%$ \\
\hline (O)sales & 4.000 & 0.0 & $0.0 \%$ & 0.6 & $14.3 \%$ & (O)sales & 4.000 & 0.0 & $0.0 \%$ & 1.0 & $25.5 \%$ \\
\hline (O)profit & 4.000 & 0.0 & $0.0 \%$ & 0.6 & $14.3 \%$ & (O)profit & 2.000 & 1.6 & $80.6 \%$ & 0.0 & $0.0 \%$ \\
\hline (O)HR and Q & 5.000 & 0.0 & $0.0 \%$ & 0.7 & $14.3 \%$ & (O) $\mathrm{HR}$ and $\mathrm{Q}$ & 5.000 & 0.0 & $0.0 \%$ & 0.0 & $0.0 \%$ \\
\hline Firm 8 & 0.750 & \multicolumn{2}{|c|}{1.000} & \multicolumn{2}{|c|}{1.000} & Firm 22 & 0.765 & \multicolumn{2}{|c|}{1.000} & \multicolumn{2}{|c|}{1.000} \\
\hline (I)HC & 3.000 & -0.8 & $-25.0 \%$ & -0.7 & $-31.7 \%$ & (I)HC & 4.000 & -1.1 & $-27.9 \%$ & 0.0 & $0.0 \%$ \\
\hline (I)SC & 5.000 & -2.0 & $-40.0 \%$ & -1.6 & $-52.4 \%$ & (I)SC & 5.000 & -1.2 & $-23.5 \%$ & 0.0 & $0.0 \%$ \\
\hline (I)CCandKC & 3.000 & -1.0 & $-33.3 \%$ & -0.7 & $-35.7 \%$ & (I)CCandKC & 2.000 & -0.5 & $-23.5 \%$ & 0.0 & $0.0 \%$ \\
\hline (I)EC & 4.000 & -1.0 & $-25.0 \%$ & -0.6 & $-19.0 \%$ & (I)EC & 4.000 & -0.9 & $-23.5 \%$ & -0.5 & $-17.4 \%$ \\
\hline (I)FC & 3.000 & -2.0 & $-66.7 \%$ & -2.9 & $-285.7 \%$ & (I)FC & 5.000 & -2.2 & $-44.7 \%$ & 0.0 & $0.0 \%$ \\
\hline (O)sales & 4.000 & 0.0 & $0.0 \%$ & 0.6 & $14.3 \%$ & (O)sales & 1.000 & 2.2 & $217.7 \%$ & 3.6 & $114.0 \%$ \\
\hline (O)profit & 4.000 & 0.0 & $0.0 \%$ & 0.6 & $14.3 \%$ & (O)profit & 1.000 & 2.5 & $252.9 \%$ & 0.0 & $0.0 \%$ \\
\hline (O)HR and Q & 1.000 & 3.0 & $300.0 \%$ & 4.7 & $117.9 \%$ & (O) HR and $\mathrm{Q}$ & 5.000 & 0.0 & $0.0 \%$ & 0.0 & $0.0 \%$ \\
\hline Firm 17 & 0.818 & \multicolumn{2}{|c|}{1.000} & \multicolumn{2}{|c|}{1.000} & & & & & & \\
\hline$(\mathrm{I}) \mathrm{HC}$ & 5.000 & -2.5 & $-50.9 \%$ & -2.3 & $-93.7 \%$ & & & & & & \\
\hline (I)SC & 3.000 & -0.5 & $-18.2 \%$ & 0.0 & $0.0 \%$ & & & & & & \\
\hline (I)CCandKC & 3.000 & -0.5 & $-18.2 \%$ & -0.6 & $-24.4 \%$ & & & & & & \\
\hline (I)EC & 4.000 & -0.7 & $-18.2 \%$ & -0.4 & $-12.2 \%$ & & & & & & \\
\hline (I)FC & 4.000 & -2.5 & $-61.4 \%$ & -2.2 & $-142.4 \%$ & & & & & & \\
\hline (O)sales & 4.000 & 0.0 & $0.0 \%$ & 0.8 & $20.0 \%$ & & & & & & \\
\hline (O)profit & 4.000 & 0.0 & $0.0 \%$ & 0.2 & $5.0 \%$ & & & & & & \\
\hline (O)HR and Q & 1.000 & 3.3 & $327.3 \%$ & 3.8 & $88.9 \%$ & & & & & & \\
\hline
\end{tabular}

operations, for instance to reduce an over-extensive and often costly use of local informal social networks and to use more formal or standardised practices. In the long run, an extensive use of social networks may reduce the competitive drive for the growth of entrepreneurship in a creative and innovative melting pot. The current isolation of the firm brings limitations, for example in the use of formal networks and cooperation (e.g. for managerial and operational support), effective break-out strategies, and new market segmentation, in particular, since local clients are not necessarily big spenders; furthermore, many clients do not visit districts of migrant entrepreneurs (diversity of customers), while fewer new product-market combinations are developed.

A more formalised and routine approach would increase the business focus on firm management (e.g., a focus on professionalisation, viz. improvements in the organisational and management structure, more emphasis on attracting highly skilled employees and on market expansion), which would not only reflect the growing diversity and dynamics of the business environment today, but also help to monitor the firm's strategic response to this complexity. The firm should, therefore, regularly adapt its organisational growth strategies in response to the market and economic conditions (so as to increase its sales).

Therefore, drawing benefits from potential formalised social capital, diversity and business opportunities demands a high level of interaction and connection within various formal and standardised networks as well as between individuals within and between cities/regions. Several of those results seem to be in line with the results obtained in a previous study by Kourtit and Nijkamp (2012). 


\section{Conclusions}

Over the past few decades, international migration has become a phenomenon of worldwide importance, in which developed countries - and mainly large cities - have acted as magnets for foreign migrants. The latter group seeks new opportunities in a host country; hence, it is clear that in the case of mass migration, various significant socio-economic effects can be expected in the country of destination.

As mentioned above, migrant entrepreneurs are not only involved in low-skill business activities in urban economies, but more and more of them (especially those with a higher education, often belonging to second-generation migrants) are involved in high-tech business and advanced branches of the service economy. This transition from traditional markets to mainstream markets is called a 'break-out strategy'. As a consequence, migrant entrepreneurs are more and more in competitive business actions on mainstream urban markets. Thus, there is a clear trend in migrant entrepreneurship towards the dovetailing of their activities in relation to the more advanced business sector in cities. Instead of a focus on a protected market, those entrepreneurs reach out to a 'normal' comparative market in an advanced economy. In conclusion, urban agglomerations offer powerful seedbeds for the economic emancipation of migrant entrepreneurs. However, their economic performance may differ vastly. This heterogeneity was explored in the present paper.

The heterogeneity of migrants promotes a great cultural diversity, mainly in large cities and urban agglomerations (e.g. in terms of cultural identity, a creative urban 'milieu' or atmosphere, access to new knowledge, orientation towards the urban embeddedness of new business initiatives, and adequate use of social and financial capital and networks). Therefore, new self-employment modes, the birth of SMEs and the internationalisation of the city can induce new (urban) economic vitality (Kourtit, Nijkamp 2011).

Cultural and socio-ethnic heterogeneity can offer various impulses that stimulate (often highly skilled) ethnic groups to resort to creative industries and to deploy urban space as a business action platform by mobilising all their human and social resources. Such a strategy can contribute to the urban economy by increasing the economic, social and cultural diversity and by offering new job opportunities to immigrants. Consequently, many modern cities have become multicultural Jacobian 'melting pots' with a great development potential.

Migrant entrepreneurship - not only as an individual business activity, but also as a collective entrepreneurial feature of new industrial districts in a city ('the melting pot' phenomenon) - is one of the fascinating manifestations of Schumpeterian urban development.

The SE-DFM model used in this empirical study seems to provide decision-makers with practical and transparent solutions available in the SE-DFM projection in order to reach the efficiency frontier, and thus to improve their performance. These results offer a meaningful contribution to decision support and planning for greater efficiency in the development of a firm's strategy. Therefore, the SE-DFM model could become a useful policy vehicle that may have great added value for operational decision-making and planning in firms. Clearly, firms have a possibility to increase their potential. This potential for improvement differs for each firm, but our results offer operational guidelines on a case-bycase basis.

In this paper, we have in particular presented a new methodology, the SE-DFM model, which integrates a super-efficiency model and a DFM model. The new method minimises the distance friction for each input and output separately. As a result, the reductions in inputs and increases in outputs that are necessary to reach an efficiency frontier are smaller than in the standard model. Furthermore, the new model could be adapted to reflect realistic conditions in an efficiency improvement projection. In conclusion, our SE-DFM model is able to present a firm's more realistic efficiency improvement strategy, and may thus provide a significant contribution supporting decision-making and planning for the improvement of the efficiency of the agents involved. Admittedly, technicalities involved in the use of generalised DEA models are rather complex, but benefits for a better understanding of the manifold backgrounds of differences in the economic performance of migrant firms are great as well; we are now able to extract quantitative 
information about the performance of those on a comparative case-by-case basis.

\section{Acknowledgements}

Financial support from the NORFACE research programme on Migration in Europe Social, Economic, Cultural and Policy Dynamics, and from the SUS.DIV (Sustainable Development in a Diverse World, 2005-2011) research programme on the relationship between cultural diversity and sustainable development is acknowledged.

\section{References}

Afonso A., Fernandez S., 2006. Measuring local government spending efficiency: Evidence for the Lisbon region. Regional Studies 40(1): 39-53.

Akgün A.A., van Leeuwen E.S., Nijkamp P., 2011. A systemic perspective on multi-stakeholder sustainable development strategies. In: Chatterji M., Gopal D., Singh S. (eds), Governance, development and conflict (Book series: Contributions to conflict management, peace economics and development, Volume 18). Emerald Group Publishing Limited: 123-146.

Anderson P., Petersen N., 1993. A procedure for ranking efficient units in data envelopment analysis. Management Science 39: 1261-1264.

Ansoff I., 1957. Strategies for diversification. Harvard Business Review 35: 113-124.

Athanassopoulos A.D., Karkazis J., 1997. The efficiency of social and economic image projection in spatial configurations. Journal of Regional Science 37(1): 375-397.

Audretsch D.B., 2002. Entrepreneurship: A survey of the literature. Prepared for the European Commission, Enterprise Directorate General, Brussels, July.

Boissevain J., Blauschkee J., Grotenberg H., Joseph I., Light I., Sway M., Waldinger R., Werbner P., 1990. Ethnic entrepreneurs and ethnic strategies. In: Waldinger R., Aldrich H., Ward R. (eds), Ethnic entrepreneurs: Immigrant business in industrial societies. Sage, London: 131-157.

Borjas G.J., 1986. The self-employment experience of immigrants. Journal of Human Resources 21(4): 485-506.

Brockhaus R.H., Sr., 1980. Risk taking propensity of entrepreneurs. Academy of Management Journal 23: 509-520.

Brush C.G., 1992. Research on women business owners: Past trends, a new perspective and future directions. Entrepreneurship Theory and Practice 17(4): 5-30.

Chaganti R., Greene P.G., 2002. Who are ethnic entrepreneurs? A study of entrepreneurs' ethnic involvement and business characteristics. Journal of Small Business Management 40: 126-143.

Charnes A., Cooper W., Rhodes E., 1978. Measuring the efficiency of decision making units. European Journal of Operational Research 2: 429-444.

Choenni A., 1997. Veelsoortig Assortiment. Het Spinhuis, Amsterdam.
Clark K., Drinkwater S., 1998. Ethnicity and self-employment in Britain. Oxford Bulletin of Economics and Statistics 60: 383-407.

Cohen W., Levinthal D., 1989. Innovation and learning. Economic Journal 99: 569-596

Constant A.F., Zimmermann K.F., 2006. Measuring ethnic identity and its impact on economic behavior. Journal of the European Economic Association 6: 424-433.

Cormack J., Niessen J., 2002. Supplier diversity, the case of immigrant and ethnic minority enterprises. Background paper prepared for the Transatlantic Round Table on Supplier Diversity, Brussels.

Dagevos J., Gesthuizen M., 2005. Niet-westerse allochtonen met een stabiele arbeidsmarktpositie: aantallen en ontwikkelingen. Sociaal en Cultureel Planbureau, Den Haag.

Dana L.P. (ed.), 2007. Handbook of research on ethnic minority entrepreneurship: A co-evolutionary view on resource management. Edward Elgar, Cheltenham.

Delft H. van, Gorter C., Nijkamp P., 2000. In search of ethnic entrepreneurship in the city. Environment $\mathcal{E}$ Planning $C$ 18: 429-451.

Dubini P., 1989. The influence of motivations and environment on business start-ups: Some hints for public policies. Journal of Business Venturing 4(1): 11-26.

Engelen E., 2001. 'Breaking in' and 'breaking out': A Weberian approach to entrepreneurial opportunities. Journal of Ethnic and Migration Studies 27(2): 203-223.

Eurostat, 2004. Eurostat yearbook: The statistical guide to Europe. OOPEC, Luxembourg.

Fagenson E.A., 1993. Personal value systems of men and women entrepreneurs versus managers. Journal of Business Venturing 8: 409-430.

Fairlie R.W., 2004. Recent trends in ethnic and racial business ownership. Small Business Economics 23: 203-218.

Fairlie R.W., 2005. Entrepreneurship among disadvantaged groups: An analysis of the dynamics of self-employment by gender, race, and education. In: Parker S.C., Acs Z.J., Audretsch D.R. (eds), Handbook of entrepreneurship. Kluwer Academic, Dordrecht.

Fairlie R.W., Meyer B.D., 1996. Ethnic and racial self-employment differences and possible explanations. Journal of Human Resources 31(4): 757-793.

Fearon J.D., 2003. Ethnic and cultural diversity by country. Journal of Economic Growth 8: 195-222.

Fischer E.M., Reuber A.R., Dyke L.S., 1993. A theoretical overview and extension of research on sex, gender, and entrepreneurship. Journal of Business Venturing 8(2): 151168.

Genc M., Gheasi M., Nijkamp P., Poot J., 2012. The impact of immigration on international trade. In: Nijkamp P., Poot J., Sahin M. (eds), Migration impact assessment. Edward Elgar, Cheltenham: 301-337.

Gheasi M., Nijkamp P., Rietveld P., 2013. Migration and foreign direct investment: Education matters. Annals of Regional Science 51(1): 73-87.

Gorter C., Nijkamp P., Poot J. (eds), 1998. Crossing borders. Ashgate, Aldershot.

Greenwood M.J., Hunt G.L., Kohli U., 1996. The short-run and long-run factor-market consequences of immigration to the United States. Journal of Regional Science 36(1): 43-66.

Halkos G.E., Tzeremes N.G., 2010. Measuring regional economic efficiency: The case of Greek prefectures. Annals of Regional Sciences 45: 603-632.

Hardin G., 1974a. Living on a lifeboat. Bioscience 24: 561-568. 
Hardin G., 1974b. Lifeboat ethics: The case against helping the poor. Psychology Today 8: 38-43.

Hodgson R., Poot J., 2011. New Zealand research on the economic impacts of immigration 2005-2010: Synthesis and research agenda. Discussion Paper CDP 04/11, University College London, London.

Jacobs J., 1961. The death and life of great American cities. Vintage Books, New York.

Jacobs J., 1969. The economy of cities. Random House, New York.

Kahanec M., Zimmermann K. (eds), 2011. Ethnic diversity in European labor markets. Edward Elgar, Cheltenham.

Kloosterman R., Rath J., 2003. Immigrant entrepreneurs: Venturing abroad in the age of globalisation. Berg Publishers, Oxford.

Kloosterman R.C., van der Leun J., Rath J., 1998. Across the border: Economic opportunities, social capital and informal businesses activities of immigrants. Journal of Ethnic Migration Studies 24: 367-376.

Kloosterman R., van der Leun J., Rath J., 1999. Mixed embeddedness: (In)formal economic activities and immigrant businesses in the Netherlands. International Journal of Urban and Regional Research 23(2): 252-266.

Kourtit K., Nijkamp P., 2011a. The new Dutch economy: New and colourful entrepreneurship. In: van Gelderen M., Masurel E. (eds), Entrepreneurship in context. Routledge, London: 187-201.

Kourtit K., Nijkamp P., 2011b. Strategic choice analysis by expert panels for migration impact assessment. International Journal of Business and Globalisation 7(2): 166-194.

Kourtit K., Nijkamp P., 2012. Strangers on the move: Ethnic entrepreneurs as urban change actors. European Review 20(3): 376-402.

Kourtit K., Nijkamp P., Arribas-Bel D., 2013a. The creative urban diaspora economy: A disparity analysis among migrant entrepreneurs. In: Kresl P., Sobrino J. (eds), Handbook of research methods and applications in urban economies. Edward Elgar, Cheltenham: 472-496.

Kourtit K. Nijkamp P., Suzuki S., 2013b. Exceptional places: The rat race between world cities. Computers. Environment and Urban Systems 38: 67-77.

Light I., 1972. Ethnic enterprises in America. University of California Press, Berkeley.

Longhi S., Nijkamp P., Poot J., 2005a. The fallacy of 'job robbing': A meta-analysis of estimates of the effect of immigration on employment. Journal of Migration and Refugee Issues 1(4): 131-152.

Longhi S., Nijkamp P., Poot J., 2005b. A meta-analytic assessment of the effect of immigration on wages. Journal of Economic Surveys 19(3): 451-477.

Longhi S., Nijkamp P., Poot J., 2008. Meta-analysis of empirical evidence on the labour market impact of immigration. Région et Développement 27(1): 161-191.

Longhi S., Nijkamp P., Poot J., 2010. Meta-analyses of labour-market impacts of immigration: Key conclusions and policy implications. Environment $\mathcal{E}$ Planning C 28: 819-833.

Macmillan W.D., 1986. The estimation and application of multi-regional economic planning models using data envelopment analysis. Papers of the Regional Science Association 60: 41-57.

Maslow A.H., 1943. A theory of human motivation. Psychological Review 50: 370-396.

Maslow A.H., 1954. Motivation and personality. Harper, New York.
Masurel E., Nijkamp P., 2003. Allochtoon ondernemerschap. In: Risseeuw P., Thurik R. (eds), Handboek Ondernemers en Adviseurs; Management en Economie van het Midden- en Klein Bedrijf. Kluwer, Dordrecht: 207-216.

Masurel E., Nijkamp P., Tastan M., Vindigni G., 2002. Motivations and performance conditions for ethnic entrepreneurship. Growth \& Change 33(2): 238-260.

Masurel E., Yuzer M., Holleman J., 2003. Ethnic minority entrepreneurs: The generation effect. An analysis of motivational differences between first and second generations. Paper presented at the International Workshop on Modern Entrepreneurship. Regional Development and Policy: Dynamic and Evolutionary Perspectives. Amsterdam, 23-24 May 2003.

Maudos J., Pastor J.M., Serrano L., 2000. Efficiency and productive specialisation: An application to the Spanish regions. Regional Studies 34: 829-842.

McClelland D.C., 1953. The achievement motive. Appleton-Century-Crofts, New York.

Metcalfe H., Modood T., Virdee S., 1996. Asian self-employment: The interaction of culture and economics in England. Policy Studies Institute, London.

Min P.G., 1987. Factors contributing to ethnic business: A comprehensive synthesis. International Journal of Comparative Sociology 28(3/4): 173-193.

Mitra J., 2012. Entrepreneurship. Innovation and regonal development. Routledge, London.

Nijkamp P., 2008. XXQ factors for sustainable urban development: A systems economics view. Romanian Journal of Regional Science 2(1): 1-34.

Nijkamp P., Pepping G., 2007. A meta-analytical evaluation of sustainable city initiatives. In: Plane D.A., Mann L.D., Button K., Nijkamp P. (eds), Regional planning. Edward Elgar, Cheltenham: 608-627.

Nijkamp P., Poot J., Sahin M. (eds), 2012. Migration impact assessment: New horizons. Edward Elgar, Cheltenham.

OECD, 2006. International migration outlook. SOPEMI 2006 edition, OECD, Paris.

Okkerse L., 2008. How to measure labour market effects of immigration: A review. Journal of Economic Surveys 22(1): $1-30$.

Ottaviano G.P., Peri G., 2006. The economic value of cultural diversity: Evidence from US cities. Journal of Economic Geography 6: 9-44.

Ozgen C., 2013. Impacts of immigration and cultural diversity on innovation and economic growth. Spatial Economics Department of VU University, Amsterdam.

Ozgen C., Nijkamp P., Poot J., 2011. Immigration and innovation in European regions. IZA Discussion Paper no. 5676, IZA, Bonn.

Rath J., Kloosterman R., 2002. The economic context, embeddedness and immigrant entrepreneurs. International Journal of Entrepreneurial Behavior and Research 8(1/2): 162 $-167$.

Razin E., Light I., 1998. Ethnic entrepreneurs in America's largest metropolitan areas. Urban Affairs Review 33: 332357.

Rusinovic K., 2006. Dynamic entrepreneurship. First and second-generation immigrant entrepreneurs in Dutch cities. Amsterdam University Press, Amsterdam.

Sahin M., 2012. Studies on migrant entrepreneurship in Dutch cities. PhD Dissertation, VU University Press, Amsterdam.

Sahin M., Nijkamp P., Stough R.R., 2010. Impact of urban conditions on firm performance of migrant entrepre- 
neurs: A comparative Dutch-US study. Annals of Regional Science 46(3): 661-689.

Sahin M., Rietdijk M., Nijkamp P., 2007. Is cultural diversity a socio-economic opportunity? A case of urban migrant entrepreneurs. Innovation - The European Journal of Social Science Research 22(3: 251-281.

Sahin M., Todiras A. Nijkamp P., and Masurel E., 2012. Economic performance of migrant entrepreneurs in the high-tech sector. In: Nijkamp P., Poot J. and Sahin M. (eds), Migration impact analysis: New horizons. Edward Elgar, Cheltenham: 227-250.

Sassen G., Thielemann E.R., 2005. A research agenda for the study of migrants and minorities in Europe. Journal of Common Market Studies 43(4): 655-671.

Schere J., 1982. Tolerance of ambiguity as a discriminating variable between entrepreneurs and managers. Academy of Management Best Paper Proceedings 42: 404-408.

Seiford L.M., Zhu, J., 2003. Context-dependent data envelopment analysis - Measuring attractiveness and progress. Omega 31, p. 397.

Shane S., Locke, E., Collins, C., 2003. Entrepreneurial motivation. Human Resource Management Review 13: 257-279.

Sjaastad L.A., 1962. The costs and returns of human migration. Journal of Political Economy 70: 80-93.

Suedekum J., Wolf K., Blien U., 2009. Cultural diversity and local labour markets. IZA Working Paper No. 4619, IZA Bonn.

Suzuki S., Nijkamp P., 2011. A stepwise-projection data envelopment analysis for public transport operations in Japan. Letters in Spatial and Resource Sciences 4 (2): 139-156.
Suzuki S., Nijkamp P., Rietveld P., 2011. Regional efficiency improvement by means of data envelopment analysis through Euclidean distance minimisation including input factors: An application to tourist regions in Italy. Papers in Regional Science 90(1): 67-90.

Suzuki S., Nijkamp P., Rietveld P., Pels E., 2010. A distance friction minimisation approach in data envelopment analysis: A comparative study on airport efficiency. European Journal of Operational Research 207: 1104-115.

Tone K., 2001. A slacks-based measure of efficiency on data envelopment analysis. European Journal of Operational Research 130: 498-509.

Tone K., 2002. A slacks-based measure of super-efficiency in data envelopment analysis. European Journal of Operational Research 143: 32-41.

Waldinger R., 1986. Immigrant enterprise: A critique and reformulation. Theory and Society 15: 249-285.

Waldinger R., Aldrich H., Ward R. (eds), 1990. Ethnic entrepreneurs. Sage Publishers, Newbury Park, CA.

Ward R., Jenkins R. (eds), 1984. Ethnic communities in business. Cambridge University Press, Cambridge.

Zhou M., 2004. Revisiting ethnic entrepreneurship: Convergencies, controversies, and conceptual advancements. International Migration Review 38(3): 1040-1074.

Zhu J., 2001. A multidimensional quality-of-life measure with an application to fortune's best cities. Socio-Economic Planning Sciences 35(4): 263-284.

Zimmermann K.F., 2005. European labour mobility: Challenges and potentials. De Economist 153(4): 425-450. 